\title{
Identity Lost and Regained: A Postcolonial Analysis of Don Shirley's Dilemma in Green Book
}

\author{
Jianmin Li \\ School of English for International Business, Guangdong University of Foreign Studies \\ Guangzhou 510420, China
}

Tel: 86-137-1941-0763Ｅ-mail: 20200310020@gdufs.edu.cn

\begin{abstract}
Kaiju Chen (Corresponding author)
Center of Business Culture and Philosophy of Culture, Institute of Hermeneutics, Guangdong University of Foreign Studies

Guangzhou, China
\end{abstract}

E-mail: 200010931@oamail.gdufs.edu.cn

Received: April 2, $2021 \quad$ Accepted: April 29, $2021 \quad$ Published: May 14, 2021

doi:10.5296/ijch.v8i1.18490ＵRL: https://doi.org/10.5296/ijch.v8i1.18490

\begin{abstract}
Images of black men in movies have been depicted negatively as brutal rioters or silly clowns at large for centuries, consolidating the stereotype that black man is inferior and subordinate compared with the white. Green Book, an Oscar-winning movie in 2019, subverts the traditional images of black men and white men, successfully portraying a well-educated black intellectual and a vulgar white driver. The present study aims to decode its success in characterizing positive images of black men, and reveal the psychological activity and identity dilemma of the hero, Don Shirley. Based on Fanon's psychoanalysis and Bhabha's hybridity theory, this paper probes into the following questions: Firstly, what kind of psychological trauma did the black hero suffer due to his black identity? Secondly, what leads to the hybrid identity of Don Shirley? The result shows that the black hero experienced the psychological trauma of inferiority complex and delusion of becoming white. He first mistook himself as a white man, then he lost his identity and finally regained a hybrid identity. Hybrid identity is attributed to cultural assimilation and otherness, which is a common phenomenon under the backdrop of colonialism. By an in-depth analysis of Don Shirley's
\end{abstract}


identity dilemma, this paper hopes to shed light on racial discrimination from the perspective of post-colonialism.

Keywords: psychoanalysis, hybrid identity, post-colonialism, inferiority complex, culture

\section{Introduction}

Movies closely demonstrate the interplay and convergence between social ideology and artworks. It mirrors public desires and social trends by character setting and plots, just as Siegfried Kracauer points out "films as popular art provide insight into the unconscious motivations and fantasies of a nation." (Kracauer, 1947: 147). Furthermore, the dissemination of movies changes and shapes public opinions, imperceptibly influence people's thinking and behavior. Concepts and ideas that films convey in the virtual world subtly influence how people view their lives (Wu Yajun, 2011:1). Thus, the study of films can reveal social ideology and problems to some degree, helping us better understand critical social issues.

Notwithstanding some improvements in black men's social status, there remain many problems unsolved in the black movie industry. Due to the profit-chasing nature of movie producers, Hollywood structurally relegates black cinema, along with other minority-audience cinemas, to marginal status (Guerrero,1993:7). The proportion of black man main character is far smaller than the white counterpart, and their remuneration contrasted are lower too (Wu Yajun, 2011:47, Fan Qingyun, 2009). Moreover, images of black men have long been solidified and otherized, portrayed as violent, evil, and brutal rioters, or as "clowns" who have an aptitude for entertainment without intelligence (Wu Yajun, 2011:47). The negative images of the black men in movies reflect problems in society, and inevitably, have a bad impact on racial equality and social harmony.

There are some recent attempts to change these stereotyping figures in Hollywood, among which, Green Book is a well-received and successful film that honored as the best picture in Oscar. It subverts the traditional expectation of black and white, depicting an intelligent, elegant, and well-educated black pianist, as well as a white driver who behaves discourteously and ignorantly. The movie unfolds the subtle identity struggle of the black intellectuals, who find himself lingering between the white world and the black world, unaware of his ethnic identity.

The present study aims to decode the success of Green Book in characterization and provide some insight into the construction of positive images of black men. Based on Fanon's psychoanalysis and Bhabha's hybridity theory, this paper probes into the following questions: Firstly, what kind of psychological trauma does the black hero suffer due to his black identity? Secondly, what leads to the hybrid identity of the major character?

\section{Literature Review}

\subsection{Psychopathy of the Colonized}

As a pioneer of post-colonial cultural criticism, Fanon paves the way for psychoanalysis in colonialism (Xi Huanhuan, 2011: 9). Working as a physician and psychiatrist, he was a French Indian who suffered from the French colonialism. Most of his works demonstrate a 
deep insight into black psychology and colonial issues. One of his most prominent books, Black Skin, White Marks, marks Fanon's huge contribution to the incisive disclosure of negroes' psychological trauma and the interdependency between the colonizer and the colonized.

Unprecedentedly, Fanon probes into the negroes' psychological trauma due to their black identity, and discovers complicated inferiority complex and delusion of becoming white. The colonized suffered from inferiority complex due to the culture (Fanon, 1952:9). They lost confidence in the history and future of the black, believing that they are inferior to the white. The colonized thought they were battered down by tom-toms, cannibalism, intellectual deficiency, fetishism, racial defects, and they took themselves far off from their own presence (Fanon, 1952:85). This can be proven by their imitation of the white culture, and by the fact that they viewed fitting into the white society as one of the most significant pursuit in their lives. They believed that white men's language could give them honorary citizenship. Moreover, the desire of becoming white overwhelmed them and thrust them into a neurotic situation (Yu Wenxiu, 2004: 25). The black women dreamed to marry white men and the black men dreamed to marry white women (Fanon, 1952:28). They hoped to enter the white world by marriage. Just as what happened in the dream of a Fanon's negro patient: "I had been walking for a long time, I was extremely exhausted, I had the impression that something was waiting for me...In this second room there were white men, and I found that I too was white." (Fanon, 1952:74). Fanon believes that his patient is suffering from an inferiority complex and he is overwhelmed by the wish to be white (Fanon, 1952:74).

Fanon argues that the negroes' psychological trauma can largely attribute to the society where the black is made inferior. To reinforce the dominant position, the colonizer assimilated and controlled negroes explicitly or implicitly, which undermined the black' mental health and caused stunning inexplicable psychological trauma (Yu Wenxiu, 2004: 25). The colonizer controlled the negroes by monopolizing colonial discourse, framing the supreme white and the subordinate and inferior black. "The Negro is bad, the Negro is mean, the Negro is ugly...Mama, the nigger's going to eat me up." (Fanon, 1952: 86). This kind of discourse was embedded in people's mindset, changing how society perceived black man, who shifted from an ordinary person to a human eater. The monopolization of language was, at the same time, the monopolization of culture, ideology, and identity. Fanon points out that the perpetuation of colonialism roots in how the society portrait black man, who symbolize savage, bad man and devil in the media and the textbooks (Fanon, 1952:113). The black identity is stereotyped, so no matter what language they speak, what they do will not change how they are perceived by white men.

Colonialism was never satisfied with inflicting its own culture on others, it subverted the content and organization of other nations, denied and defamed other's history and culture (Fanon, 2007: 9). They depicted a backward society of negro, implying that their culture should be abandoned to accept the new one. Under these circumstances, a sense of inferiority and discontent emerged in the black.

The interdependency between the colonized and the colonizer is also profoundly revealed in 
Fanon's work. The black acting as "other" develops the superiority of the white, while the presence of the white proves the existing value of the black. The essential relationship of these two racial groups is mutually exclusive and mutually interdependent (Liu Haijing, 2013:33).

\subsection{Hybridity of Identity}

Homi Bhabha's criticism of colonialism aims at unearthing the possibility for resistance in the colonial text and discourse (He Yugao, 2012:99). Among his theoretical contributions, the hybridity theory put forward in the 1980s, is deemed as the most innovative and influential idea of Homi Bhabha, which mainly deals with identity dilemma (He Yugao, 2012:5). Hybridity can be interpreted as the wreckage of wholeness, or to be understood in an adversarial way, against what is not hybrid (He Yugao, 2012: 42). Huddart further explains hybridity refers to the fact that cultures are not a discrete phenomenon; instead, they are always in contact with one another, and this contact leads to cultural mixed-ness (Huddart, 2005:4).

Intrinsically, the ambiguity and uncertain nature of social discourse cause hybridity. The colonizer endeavors to oppress and exploit the colonized physically and mentally with the help of monopolistic discourse. However, the intrinsic attributes that language incline to be ambiguous and indefinite, along with cultural differences, prevent the complete transcription of the black language, thus producing a mixture of the indigenous language and targeted language (Bhabha, 1996:22). The hybridity of language causes the hybridity of culture. Hybridity in culture shapes indefinite and uncertain identity, and more importantly, nurtures potent strength to break the ethnic boundary (Wang Ning, 2002:50).

The process that gives rise to hybridity is identified as mimicry, where the colonized learn and imitate such things as culture, language, the legal system of the civilized country in an awkward way. According to Bhabha, mimicry "is the desire for a deformed, recognizable other, as a subject of a difference that is almost the same, but no quite."(Bhabha, 1996:86). In other words, mimicry as Bhabha understands is an exaggerated copying of language, culture, manners, and ideas. This exaggeration means that mimicry is repetition with difference, so it is not evidence of the colonized's servitude. In fact, this mimicry also is a form of mockery (Huddart, 2005:39). Hybridity is produced when the colonized mistakenly imitate the culture in the civilized country, which adds personal assumption and interpretation into the translation of culture.

Mimic man, who partially absorbs others' culture, faces an identity dilemma of unaware of which ethnic group he belongs to. Particularly, black intellectuals with white education background suffer most from multi-layer identity and ambiguous cultural recognition. They have the feeling of nostalgia for the colonized homeland and desire for a civilized world (Bhabha, 2013:304). Although those black intellectuals have internalized western values, they bear a distorted and conflicting affection toward the west since ethnic discrimination is the consequence of the prevalence of western cultures (He Yugao, 2012:177).

In Bhabha's opinion, the colonial ideology is full of cracks, so the colonized can resist the 
prevalence of colonialism by imitating the culture of the colonizer, by redeveloping those cultures in his own way, to create the zone of hybridity. Hybridity makes it harder to distinguish the boundary between the black and the white, the colonial dichotomy is disintegrated, and the imagined "other" disappear (Bhabha, 1996:23). Moreover, as the white lose the mirrored "other", they will be overwhelmed by a sense of worry that their supremacy over the black may fade away.

\section{A Postcolonial Analysis of Don Shirley}

\subsection{Psychoanalysis of Don Shirley}

Using Fanon's psychoanalysis as a guideline, an in-depth study of Green Book is conducted to demonstrate the thinking pattern and identity dilemma of black intellectuals, with the hope to shed light on black psychology.

The backdrop of the film is set in a dark history for the black. In the 1950s, black men in south America suffered from serious racial discrimination, which prevented black travelers from living and eating in south America even for a short period of time. Therefore, a Green Book aiming to help black men find safe hotels and restaurants was launched by a black mailer Victor Green (Liu Zhiyu et al, 2020:2). This book provided detailed information for northern black visitors in terms of living, eating, and traveling, and it symbolizes the dark time when black segregation prevailed. At that time, sundown town where black was forbidden to enter after sunset still existed, which reflected the inveterate white supremacy and white hegemony (Liu Zhiyu et al, 2020:132). Under such historical background, the film Green Book portrays how the black pianist, Don Shirley, managed to perform in south America with the accompany of the white driver, Tony Vallelonga.

Don Shirley was a typical black intellectual. Born in a prestigious and relatively affluent family, Dr. Don Shirley was a well-educated black pianist who behaved elegantly in north America. Distinguished and prominent as Don Shirley was, the discriminating environment he lived in negatively impacted how he perceived himself as a black and how he reacted to black cultures. His psychology was an epitome of black intellectuals. They suffered most from serious cultural alienation and mental trauma, due to the white domination, cultural aggression, and racial discrimination brought by colonial rule (Yu Wenxiu, 2004:25).

The inferiority complex of Don Shirley was implicit. Fanon claims "every colonized people in his soul has an inferiority complex." The song they sing, the magazine they read, the historic book they learn are full of discriminating language, depicting evil, foolish, and vicious black men (Fanon, 1952:114). When asked about the ivory ornaments, which imply the slavery history, in the house, he avoided being projected with the stereotype of African Americans. He refused to eat fried chicken, refused to black jazz music, and avoided black pronunciation, showing that he felt shameful toward his own culture, language, and things symbolizing black.

Moreover, Don Shirley felt perplexed toward this own identity and yearned for becoming white. Witnessing Tony gambled with a gang of black men, he endeavored to distinguish himself from them and said that those black man's birth determines their destiny. On his way 
back, when he stood in front of a group of black men working in the field, he behaved uncomfortably and awkwardly since he as a black man lived a far more well-off life than them. These details demonstrate he did not regard himself as a black man. Furthermore, deep down in his heart, he aspired to fit into the white world. The education he received prodded him to act like a white man, eat like a white man, and speak like a white man because social norms and values were established by the white. Therefore, he made strict regulations on himself, listening to white music, behaving elegantly and gently, being strict with his pronunciation to make sure that it was consistent with that of the white. However, he belonged to neither group, only finding himself a wretched lonely object in this dazzling world. Just as Don Shirley confessed, "So if I am not black enough, and if I am not white enough, then tell me, what am I?"

The reason behind this lies in the interdependent relationship between the colonized and the colonizer. Fanon believes that "when a black man contacts with the white world he goes through an experience of sensitization. His ego collapses. His self-esteem evaporates" (Fanon, 1952:8). The white dominate social discourse and construct images for themselves. As the "other" of this contrived system, the black represent impoverished and backward people. The existence of the enlightened and pure white relies on the presence of the black standing for evil and backward. On the contrary, the black lose their meaning for existence without the white (Liu Haijing, 2013:33). The divide between black skin and white mark is not a neat division, but instead is "a doubling, dissembling image of being in at least two places at once." (Nagy-Zekmi, 2007:5).

This kind of feeling is typical of black intellectuals. Fanon's split subject should not be read as the paradigmatic colonized subject: the psychic dislocations he points out are most likely to be felt by native elites or those colonized individuals who have been educated within and, to some extent, invited to be mobile within the colonial system rather than by those who were at the margins (Nagy-Zekmi, 2007:5).

\subsection{Hybrid Identity of Don Shirley}

\subsubsection{Mistaking of Identity}

At first, Don Shirley recognized himself more of a white man than a black man and tried his best to imitate the white's manners and behavior.

Notwithstanding his black skin, the education Don Shirley received is typical of the white society and white culture. He was keen on playing the piano rather than jazz, drinking wine rather than beer, being well-restricted and courteous. He knew more about the white culture than the black culture, just as Tony said "I think I am more of a black than you." When he was living in north America, his preoccupation was how to improve his musical performance and where to perform. The reputation and admiration from others convinced him that he was an elegant pianist fit into the white supreme world rather than the black society. He lived a totally different life as an African American, far from the afflicting discriminated experience his ethnic groups had suffered.

As the beginning of the film shows, Don Shirley lived a prestigious and peaceful life that 
belonged to elites with high social status. His house was well-furnished with all kinds of precious collection and treasures, he hired a housekeeper to clean his house and a secretary to handle some work, which all showed that he was affluent and of high social standing. When Dr. Don Shirley was eating in the canteen, people around felt comfortable with his presence, which was contrasted with the discriminated treatment he received later. Besides, despite his black skin, he didn't have an inferiority complex when it came to the white, rebutting Tony when he made mistakes in the name of the music, asking Tony to stop smoking in the car, and sometimes despise Tony's bad manners. His relationship with Tony, the white, was rather equal. All these indicate his wrong judgement of his true ethnic identity. In his opinion, since he enjoyed the same well-off life as the white elite, he belonged to the white society and should be respected in the same way.

Furthermore, Dr. Don Shirley's recognition of his black ethnic identity was vague and dubious. He did not regard himself as a part of the black society. When asked about the ivory ornaments, which imply the slavery history, in the house, he avoided being projected with the stereotype of African Americans. Seeing Tony gamble with a group of impoverished black men, Shirley tried to distinguish himself from them, remarking that their birth determined their destiny. This shows that Don tried every means to distinguish himself from his own ethnic group, for one thing, black always symbolizes backward and poor, and for another, he wanted to escape form the truth that he was a black man.

To some extent, the mimicry was implied in this film. The culture, language, and ideology of the white was assimilated by Don Shirley. The adaption of white culture strengthens the superior position of the white by attaching the white to all the wonderful things in the world e.g. purity, civilization, and intelligence. Don Shirley regarded himself as a white so he restricted himself to act like a white man. In fact, he was trying to mimic the white.

\subsubsection{Identity Lost}

Although Don Shirley recognized himself as the white, in his visit to the south, he awoke to the reality and found that he belonged to neither the white world nor the black world. He lost his perceived identity as a result of the discrimination he received.

Don Shirley came to realize he wasn't accepted by the white. His tour south witnessed a great shift in how black intellectuals were treated. In the bar, Shirley was challenged by a gang of white men and bit without any reason, and they told Shirley to "get out of my place". He didn't fit into the white world, and he was rejected by a suit shop, despised by the police, and forbiden to use the toilet for his color. One day, Tony drove into the sundown town where the black man was supposed to leave after sunset, and they were ill-treated and detained in the police office. The discrimination he received always reminded him that he was not accepted by the white, which contradicted with his perceived identity and drove him into antagonization.

On the other hand, Don Shirley did not belong to the black. He was perplexed about the black community because he and the black didn't share identical educational background, thinking pattern, and behavior. On his way back, he saw a group of black farmers working laboriously in the field, from their face one can tell they lived a wretched and impoverished life. When 
those farmers saw Don Shirley, who wore a tidy suit, accompanied by a personal driver, they stared at him with confusion and curiosity, as if looking at something they had never known before. Don Shirley avoided looking back directly in his eyes, maybe because he was embarrassed by their starring eyes, or because it was a harsh reality that he and those poor black farmers shared the same ethics. He should be like them but he wasn't. Moreover, his habits and hobbies betrayed him. Rather than jazz and fried chicken, he preferred piano and top-quality food. He was careful with his pronunciation, his dressing, his manner, and talk back to Tony when he threw rubbish out of the window and he gambled with a gang of black men. He never behaved, talked, and spoke like a black man, but the discrimination always reminded him that he was nothing more than a black.

After being distained in the sundown town, he was nearly at the edge of collapse, and he confessed to Tony that he had to endure teasing and contempt from the white for his entire life. Tony told Don that "You don't know anything about your own people, what they eat, how they talk, how they live". Although Don did not agree with what Tony said and argued back, he clearly knew Tony was right, he could hardly fit in the black world. The argue between them drove Don to despair and misery, and Tony's words further stroke him, so he commanded Tony to pull over and walked in the rain alone. He told Tony what confused him, that he did not know who he was. At this point, Don realized that the rich white people paid him to play the piano because this made them feel cultured. As soon as he stepped off the performing stage, he turned into being another nigger to them. He said "Because that is their true culture". And he suffered that contempt alone, because he was not accepted by his own people, because he was not like them either. He cried out "So if I am not black enough, and if I am not white enough, and if I am not man enough, then tell me, Tony, what am I?". Those sentiment had been suppressed for a long time, and the ultimate outbreak demonstrated the inner fear in Don, that he felt lost in terms of his identity. The loss of identity was not only the consequence of the discriminated treatment he received from the white, but also because of his feeling of being estrange and unfamiliar toward his own ethnic group. Also, the distinct contrast between him and Tony enlightened his location of his own identity. Tony said he knew exactly who he was, he was the guy who's lived on the same neighborhood in the Bronx with his mother, his father, his brother, and now his wife and kids. This answer prodded Don to reflect on his own identity, who he was and where he belonged to. Finally, he was trapped in the dilemma of finding himself alone, without clear identity.

In fact, Don Shirley has a hybrid identity. The hybridity of identity is the consequence of colonialism. To assimilate the colonized people, the colonizers ceaselessly pour cultures, ideology, and beliefs into the former's mind. They try to establish their status by portraying the opposite as the inferior, the weaker. The black intellectuals, however, lose their identity in this process of learning and adapting. They internalize European culture, but due to the discrimination attached to this culture, they cannot fully agree with this culture, which leads to the hybridity of identity and the emerge of contradictory feelings (He Yugao, 2012:102).

\subsubsection{Identity Regained}

What Don Shirley had been through in the south convinced him that he would not be 
accepted as a white for his color. These unexpected obstacles encountered by Dr. Don Shirley, whose established identity was undermined, coerced him to seek and explore a new stage mentally.

In the last scene, Dr. Shirley accepted his color and the meaning it implied. He played black music in the bar, within a group of black men. People around felt delighted at the music, and it was the first time he felt so fulfilling playing the piano. He felt at ease with eating fried chicken with hands, which he could hardly accept before. These symbolize that although he was different from those black people, he can still manage to get along well with them. Besides, Don was invited to Tony's home to celebrate Christmas eve, and Tony's family felt comfortable with the presence of Don Shirley. Tony' s wife expressed her gratitude to Don for his help in writing those romantic letters. It all shows there is possibility that the two ethnic groups view each other equally and get along well with each other. Don understood the society defined who he was by his color, rather than his talent and capability. It was unnecessary to deliberately pretend to be white, because all people in the world should be equal, he just need to be himself. The hybrid identity still existed, but he found a position in between, realizing that ethnic equality was what we should strive for, instead of crowding into the white world.

The position of black intellectuals is called the third space by Bhabha. According to Homi Bhabha, in this limited space, cultural differences give rise to certain connections, combinations, and imaginative constructions of cultural and national identity (Jin Chunying \& Tian Yao, 2020: 171) Dr. Shirley was in the third space where was an intermediate position between the black world and the white world, and he regained his identity by recognizing the existence of such space. As is suggested by Bhabha, identities are incomplete, indicated by psychoanalysis, no matter it is individual or collective identities. This incompleteness is not a problem to be solved, and principally there is no full or complete identity. Instead, the incompleteness of identity needs to be acknowledged (Huddart, 2005:6). This acknowledgement of identity is different from the traditional ways of thinking. Traditional idea about the world is full of perpetuate inequalities between countries and peoples. It stresses that the relationship between one's self and others, between two subjects or objects are different. Cultures are viewed as stable, discrete and the division of cultures are distinct. However, Bhabha abandons this way of thinking and proposes that the division of one's self and other is obscure and indirect. The hybrid identity eliminates the clear boundary between one ethnic and another, thus creating an opportunity to diminish inequality.

Back in the movie, Don Shirley began to take himself as a part of the black ethnic with white educational background, though he may seem outstanding. He was just an epitome of a large group of black intellectuals in the society, and the number is growing as the society develops. They belong to mimic man in the third space, with hybrid identity. The mimicry of the black causes anxiety in the colonizer, because the distinction between them become obscure, undermining the dominant ideology that the colonized are inferior than the colonizers (Huddart, 2005 :4). In face of the same capability, same education, same decent manner of black intellectuals, the white start to be perplexed of their presumed superiority. They keep questioning themselves whether the differences still exist and where the boundary is. This 
tension between the illusion of difference and the reality of sameness leads to anxiety, and may serve as a break for the inequality (Huddart, 2005:4). Bhabha points out, this anxiety opens a gap in colonial discourse - a gap that can be exploited by the colonized, the oppressed. This anxiety enables the colonized to resist colonial authority through mimicry, a strategy of doubling or repetition. This implies that, firstly, Don Shirley can regain his own identity by recognizing the third space that lies in between two ethnic groups; secondly, the existence of hybridity is important since they can be exploited by the oppressor to resist the unsatisfactory reality.

\section{Racial Discrimination: From Don Shirley to George Floyd}

Green Book symbolizes the undeniable and cruel racial oppression in America back in the 1950s. In the movie, Don Shirley was discriminated as a black man, prohibited from entering sundown town publicly, rejected from using the same toilet of the white man, and hit out of no reason in the bar. With the development of modern civilization, racial discrimination seems to have been mitigated, but in fact, it still permeates in every facet of culture and hard to eradicate. This inequal side of the society only changed superficially in the past few decades, and continue to exist in a more subtle and covert way. Devah Pager and Hana Shepherd (2008:1) point out that unlike in the pre-civil rights era, when racial prejudice and discrimination were overt and widespread, today discrimination is less readily identifiable.

Some racial inequities are under the disguise of institution. A 2001 survey, for example, found that more than one-third of blacks and nearly $20 \%$ of Hispanics and Asians reported that they had personally been passed over for a job or promotion because of their race or ethnicity (Schiller, 2004:3). Educational institution also witnesses racial discrimination that black students are subject to comparatively less opportunity to enter top universities. These kinds of problems are hard to discover and prove, since they can be disguised easily by other excuses, e.g. the company chooses not to hire the black may argue that the black ones are not capable enough or they just do not fit in.

Law enforcement faces the same problem. Black Americans are disproportionately arrested, convicted, and incarcerated on drug charges (Fellner, 2009:1). The reason behind is difficult to tell, whether it is simply because larger proportion of Black Americans are drug addicts, or racial discrimination involves in the process of law enforcement. Until recently, the killing of George Floyd by a policeman brought racial issue in law enforcement back under the spotlight. George Floyd, a black man, was arrested for being accused of buying with a bogus bill in Minneapolis. A white policeman knelt on Floyd's neck for more than nine minutes, with his hands tied on handcuffed and lying on the ground, during which time Floyd stopped breathing and died. It stirred up local protests against inequality and policemen's abuse, and then they spread worldwide in over 60 countries, with the slogan of "Black Live Matter". This shows a worldwide pursuit of racial equity as well as the reformation and defund of police departments.

Reflecting on the tremendous and widespread impact George Floyd's death has on the society, one can say that racial problems deserve more attention from the public and the government. It is essential to a peaceful and civilized society. The root of racial inequity always is the culture of the society, just as what Fanon and Bhabha have argued. From the perspective of 
psychopathology, Fanon explains how the white culture persecutes the black people, inflicting great mental damage on their bodies. The society portrays black men as savages, bad men, devil in the text books and media, thus strengthening the oppression and perpetrating the inequity (Fanon, 1952:113). Homi Bhabha extends Fanon's research, and specifies the cultural elements behind identity dilemma of the black. The ambiguity and uncertain nature of social discourse cause a mixture of the indigenous language and targeted language, which shapes the hybridity of culture (Bhabha, 1996: 86). Bhabha's writing emphasizes the hybridity of cultures, which on one level simply refers to the mixed-ness, or even 'impurity' of cultures - so long as we don't imagine that any culture is pure (Huddart, 2005: 4). This idea provides us with an unprecedented view to resist discrimination, that is to mimic the colonizer. The mimicry causes anxiety in the colonized who believe they are superior than the black, because the boundary between them becomes blur as they try to imitate one another. The death of George Floyd alarms us of the severity of racial problems, and the study of Fanon and Bhabha do enlighten us from the perspective of culture. Therefore, Movie as an important form of culture, has a special role to play. We should pay more attention to the construed world in films, where different ethnic group should be equal and avoid stereotyping model of black men. Also, the proportion of positive images of black men should be increased to show a whole picture that the black not only involves rape, crime, and drug, but also includes such good characteristics as kind, intelligent and assiduous. Though the change of culture takes time, action always counts.

\section{Conclusion}

Green Book is a milestone in movies of black men, for it successfully subverts the expected images for the black, revealing the psychological conflicts of a black intellectual and depicting his identity dilemma. Black intellectuals suffer from the inferiority complex and delusion of becoming white, because of the assimilation strategy in colonialism and the penetration of otherness. Black man's hybrid identity attributes to the adaptation of the white culture, and he may go through the processes of identity lost and regained. Besides, in comparison with the mimic man, white man feel anxiety as they can't find the inferior other. This serves as a gap for undermining the discriminated culture, and sheds light on the improvement in the modern society.

Despite some criticisms about such film (Ju Wei, 2019; Hao Luxuan, 2019), Green Book is a meaningful attempt in changing the stereotype of black images, which is in line with the racial equality movement in contemporary society. The subversion of movie characters provides people with the possibility of constructing positive images of black people. To some extent, this movie instills the idea of equality into people's mindset, though it may seem slight, can be accumulated as a great leap in the future.

\section{References}

Bhabha, H. K. (1996). The location of culture. Routledge Classics.

Bhabha, H. K. (Ed.). (2013). Nation and narration. Routledge. https://doi.org/10.4324/9780203388341

Fan, Q. Y. (2009). Explore the cultural factors of racial discrimination in Hollywood films. 
Master's Dissertation, Shanxi Normal University.

Fanon, F. (1952). Black Skin, White Masks. London: Pluto Press.

Fanon, F. (2007). The wretched of the earth. Grove/Atlantic, Inc.

Fellner, J. (2009). Race, drugs, and law enforcement in the United States. Stan. L. \& Pol'y Rev., $20,257$.

Guerrero, E. (2012). Framing blackness: The African American image in film. Temple University Press. https://doi.org/10.2307/j.ctvrdf2mb

Hao, L. X. (2019). An Interpretation of the Screen Image of "Magical Negro" in Green Book. Radio \& TV Journal, (10), 120-121. https://doi.org/10.19395/j.cnki.1674-246x.2019.10.065

He, Y. G. (2012). Homi Baba's Hybrid Identity Theory. China Social Sciences Press.

Huddart, D. (2005). Homi K. Bhabha. Psychology Press. https://doi.org/10.4324/9780203390924

Jin, C. Y., \& Tian, Y. (2020). An analysis of the identity of Don Shelly in the Green Book based on Homi Baba theory. Satellite TV and broadband multimedia, (03), 170-171.

Ju, W. (2019). "Magic Negro" and "White Savior" - The portrayal of character image and race relations in the film Green Book. Journal of Beijing Film Academy, (04), 69-73. https://doi.org/CNKI:SUN:WSDS.0.2020-03-089

Kracauer, S. (2019). From Caligari to Hitler: A psychological history of the German film. Princeton University Press. https://doi.org/10.1515/9780691192086

Liu, H. J. (2013). The Psychoanalytic Implications and Limits of Post-colonial Cultural Theory - From Fanon to Said. Philosophical Trends, (07), 32-38.

Liu, Z. Y., \& Qi, Z. Y. (2020). Race, Power and Ideology -- An Analysis of the Key Words of Racial Discourse in the Film Green Book. Journal of North China University of Science and Technology (Social Science Edition), (03), 131-135. https://doi.org/CNKI:SUN:HLXB.0.2020-03-024

Nagy-Zekmi, S. (2007). Frantz Fanon in New Light: Recycling in Postcolonial Theory. Journal of Caribbean Literatures, 4(3), 129-139.

Pager, D., \& Shepherd, H. (2008). The sociology of discrimination: Racial discrimination in employment, housing, credit, and consumer markets. Annu. Rev. Sociol, 34, 181-209. https://doi.org/10.1146/annurev.soc.33.040406.131740

Schiller, B. (2004). The Economics of Poverty and Discrimination (9th ed.). Upper Saddle River, NJ: Pearson Prentice Hall.

Wang, N. (2002). Narration, Cultural Positioning and Identity: Homi Bhabha's Post-Colonial Critical Theory. Foreign Literature Review, (06), 48-55. https://doi.org/10.16430/j.cnki.fl.2002.06.012 


\section{Macrothink}

International Journal of Culture and History

ISSN 2332-5518 2021, Vol. 8, No. 1

Wu, Y. J. (2011). I have a dream - A brief analysis of the evolution of black images in American movies. Sichuan Provincial Correspondence Institute for Administrators, (01), 40-47. https://doi.org/CNKI:SUN:GHXY.0.2011-01-011

Xi, H. H. (2011) A Study of Fanon's Post-Colonial Theory. Master's Dissertation, Sichuan International Studies University.

Yu, W. X. (2004). Analysis on the thoughts of Fanon, a pioneer of post-colonial criticism theory. Journal of Literary Criticism, (05), 24-28. https://doi.org/10.16566/j.cnki.1003-5672.2004.05.004

\section{Copyrights}

Copyright for this article is retained by the author(s), with first publication rights granted to the journal.

This is an open-access article distributed under the terms and conditions of the Creative Commons Attribution license (http://creativecommons.org/licenses/by/4.0/) 